\title{
OPTIMASI PEMBUATAN KOPI BIJI PEPAYA (Carica papaya)
}

\author{
MARIATI \\ Jurusan Teknologi Industri Pertanian, Politeknik Negeri Tanah Laut, Jl. A. Yani, Km 6 , \\ Ds. Panggung, kecamatan. Pelaihari, kabupaten Tanah Laut, Kalimantan Selatan
}

Naskah diterima : 30 April 2015; Naskah disetujui : 30 Mei 2015

\begin{abstract}
ABSTRAK
Kopi merupakan minuman populer saat ini yang memiliki rasa dan aroma khas yang disukai oleh hampir semua kalangan masyarakat, namun kopi dapat menyebabkan ketergantungan yang disebabkan oleh kandungan kafein dalam kopi. Biji pepaya berpotensi untuk dijadikan kopi tanpa kafein. Proses pembuatan kopi biji pepaya melalui 2 tahapan yaitu optimasi cara pengeringan dan optimasi waktu penyangraian. Parameter uji yang dilakukan antara lain uji kadar air, uji fitokimia, uji kafein dan uji organoleptik. Analisis data yang digunakan adalah uji Anova yang dilanjutkan dengan uji DMRT (Duncan Multiple Range's Test). Berdasarkan hasil pengujian dan uji organoleptik, diperoleh perlakuan terbaik dengan menggunakan pengeringan sinar matahari dan waktu penyangraian selama 10 menit dengan kadar air 7\%. Hasil uji kafein menunjukkan bahwa kopi biji pepaya tidak mengandung kafein, sehingga aman karena tidak akan menyebabkan ketergantungan.
\end{abstract}

Kata kunci : kopi, biji pepaya, produksi, optimasi, Carica papaya

\section{PENDAHULUAN}

Pepaya (Carica papaya) merupakan tanaman buah yang telah menyebar luas di Indonesia. Hampir di semua daerah pepaya dapat tumbuh dengan baik. Keberadaan pepaya tidak asing lagi bagi masyarakat di Kabupaten Tanah Laut. Buah pepaya memiliki tekstur yang lembut ketika sudah masak dengan rasa yang enak dan hampir semua orang menyukai buah tersebut. Selain rasanya yang enak buah pepaya juga memiliki kandungan nutrisi dan vitamin yang relatif tinggi, hal ini tentu sangat baik bagi yang mengkonsumsi buah tersebut. Seiring dengan meningkatnya konsumsi buah pepaya, biji pepaya yang memiliki rasa pahit hanya dibuang begitu saja dan tidak ada yang memanfaatkannya. Perlu diketahui bahwa tidak hanya buah pepaya yang memiliki kandungan yang bagus untuk tubuh tetapi biji pepaya juga memiliki kandungan yang tidak kalah dengan buahnya.

Biji pepaya mengandung senyawa-senyawa steroid. Kandungan biji dalam buah pepaya kira-kira $14,3 \%$ dari keseluruhan buah pepaya. Selain mengandung asam-asam lemak, biji pepaya diketahui mengandung senyawa kimia lain seperti golongan fenol, alkaloid, triterpenoid dan saponin (Warisno, 2003). Secara tradisional biji pepaya dapat dimanfaatkan sebagai obat cacing gelang, gangguan pencernaan, diare, penyakit kulit, kontrasepsi pria, bahan baku obat masuk angin dan sebagai sumber untuk mendapatkan minyak dengan kandungan asam-asam lemak tertentu (Warisno, 2003). 
Berdasarkan berbagai kandungan yang ada di dalam biji pepaya, maka dibuatlah biji pepaya tersebut menjadi kopi biji pepaya. Ide ini muncul karena biji pepaya memiliki rasa yang pahit sehingga lebih cocok jika dibuat menjadi kopi. Kopi merupakan minuman populer saat ini yang memiliki rasa dan aroma khas yang menjadikan kopi disukai oleh hampir semua kalangan masyarakat.

\section{METODE PENELITIAN}

Optimasi pembuatan kopi biji yang dilakukan yaitu optimasi cara pengeringan dan optimasi waktu penyangraian, sedangkan metode yamg dilakukan dalam kedua optimasi tersebut adalah uji kadar air, uji fitokimia dan uji organoleptik. Kadar air merupakan banyaknya air yang terkandung dalam bahan yang dinyatakan dalam satuan persen.Kadar air juga merupakan karakteristik yang sangat penting dalam bahan pangan karena air dapat mempengaruhi penampakan, tekstur, serta ikut menentukan kesegaran dan daya awet bahan pangan tersebut. Kadar air menyebabkan mudahnya bakteri, kapang dan khamir untuk berkembang biak sehingga akan terjadi perubahan pada bahan pangan (Haryanto, 1992). Uji fitokimia adalah cara yang dilakukan untuk menentukan ciri komponen bioaktif suatu ekstrak kasar yang mempunyai efek racun atau efek farmakologis lain yang bermanfaat bila diujikan dengan sistem biologi (Harborne, 1987). Uji fitokimia biasanya meliputi uji terhadap adanya alkaloid, steroid, triterpenoid, fenolik, flavonoid, dan saponin. Uji organoleptik merupakan cara pengujian dengan menggunakan indera manusia sebagai alat utama untuk pengukuran daya penerimaan terhadap produk.

\section{Alat dan Bahan}

Alat yang digunakan dalam peneliatian ini adalah blender, neraca analitik, timbangan digital, pisau, baskom, nampan atau nyiru, spatula, wajan, ayakan, sendok, alat-alat gelas, hot

plate, neraca analitik, pengaduk, pipet tetes, pipet ukur, alumunium foil dan kertas saring. Sedangkan bahan yang digunakan dalam penelitian ini adalah serbuk kopi biji pepaya, $\mathrm{HCl} 2 \mathrm{~N}$, akuades, perekasi Meyer, pereksi Wagner, perekasi Dragendorff, etanol absolut, serbuk magnesium, $\mathrm{HCl}$ pekat, petroleum eter, asam asetat, asam sulfat pekat, reagen parry (cobalt nitrat-metanol), dan $\mathrm{NH}_{4} \mathrm{OH}$.

\section{Prosedur Kerja}

\section{A. Prosedur Kerja Pembuatan Kopi Biji Pepaya dengan Optimasi Cara Pengeringan}

Buah pepaya yang sudah matang dibelah dan diambil bijinya. Dicuci biji pepaya hingga bersih. Biji pepaya yang telah dicuci ditiriskan, kemudian ditimbang sebanyak $300 \mathrm{~g}$. Biji pepaya kemudian dikeringkan dengan optimasi pengeringan yaitu sampel A dikeringkan dengan sinar matahari suhu $35^{\circ} \mathrm{C}$ selama 9 jam, sampel B dikeringkan dengan suhu ruang $30^{\circ} \mathrm{C}$ selama 96 jam dan sampel $\mathrm{C}$ dikeringkan menggunakan oven suhu $70^{\circ} \mathrm{C}$ selama 4 jam. Biji pepaya yang telah kering kemudian disangrai. Setelah matang biji pepaya dihancurkan menggunakan blender, kemudian diayak sampai menghasilkan bubuk kopi biji papaya. 


\section{B. Prosedur Kerja Pembuatan Kopi Biji Pepaya dengan Optimasi Penyangraian}

Buah pepaya yang sudah matang dibelah dan diambil bijinya. Dicuci biji pepaya hingga bersih. Biji pepaya yang telah dicuci ditiriskan, kemudian ditimbang sebanyak $300 \mathrm{~g}$. Biji pepaya kemudian dikeringkan dengan cara pengeringan menggunakan sinar matahari. Biji pepaya yang telah kering kemudian dilakukan optimasi waktu penyangraian yaitu sampel A1 selama 5 menit, sampel A2 selama 10 menit dan sampel A3 selama 15 menit. Setelah dilakukan penyangraian biji pepaya dihancurkan menggunakan blender, kemudian diayak sampai menghasilkan bubuk kopi biji papaya.

\section{Prosedur Uji Kadar Air}

Berikut ini adalah langkah-langkah untuk menentukan kadar air bubuk kopi biji pepaya yaitu : Bubuk kopi biji pepaya ditimbang dalam neraca analitik sebanyak 1,00 g (berat awal). Setelah itu bubuk kopi biji pepaya dimasukkan kedalam oven dikeringkan pada suhu $105^{\circ} \mathrm{C}$ selama 3 jam. Setelah 3 jam bubuk kopi biji pepaya tersebut didiamkan beberapa saat sampai dingin. Lalu ditimbang beratnya dan dicatat hasilnya (berat akhir). Dioven kembali selama 30 menit, kemudian didinginkan dan ditimbang beratnya, diulangi hingga beratnya konstan. Penentuan kadar air dapat menggunakan rumus berikut :

$$
\text { Kadar air }(\%)=\frac{\text { berat awal-berat akhir }}{\text { berat awal }} \times 100 \%
$$

\section{Prosedur Uji Fitokimia}

1) Prosedur Uji Alkaloid

Ditimbang bubuk kopi biji pepaya sebanyak 0,5 g. Ditambahkan $1 \mathrm{ml} \mathrm{HCl} 2 \mathrm{~N}$ dan 9 $\mathrm{ml}$ akuades. Dipanaskan di atas penangas air selama 2 menit. Didinginkan dan disaring. Kemudian dilakukan uji alkaloid dengan cara : (1) Sebanyak 3 tetes filtrat ditambah dengan 2 tetes larutan pereaksi Meyer, akan terbentuk endapan menggumpal berwarna putih atau kuning. (2) Sebanyak 3 tetes filtrat ditambah dengan 2 tetes larutan pereaksi Wagner, akan terbentuk endapan berwarna coklat sampai hitam. (3) Sebanyak 3 tetes filtrat ditambah dengan 2 tetes larutan pereaksi Dragendorff, akan terbentuk endapan kekeruhan.

2) Prosedur Uji Flavonoid

Sebanyak $1 \mathrm{~g}$ bubuk kopi biji pepaya dimasukkan dalam tabung reaksi. Ditambahkan 5 $\mathrm{ml}$ etanol absolut, dikocok dan dipanaskan dalam penangas selama 10 menit. Setelah itu dikocok kembali kemudian disaring dan ditambahkan 0,2 g serbuk magnesium serta 3 tetes $\mathrm{HCl}$ pekat pada filtrat. Campuran dikocok dan didiamkan hingga memisah. Flavonoid positif jika terjadi warna merah, kuning atau jingga.

3) Prosedur Uji Saponin

Sebanyak 0,5 g kopi biji pepaya dimasukkan ke dalam tabung reaksi. Ditambahkan 10 $\mathrm{ml}$ air panas, didinginkan kemudian dikocok selama 10 detik. Jika terbentuk busa setinggi 1 sampai $10 \mathrm{~cm}$ yang stabil tidak kurang dari 10 menit dan tidak hilang dengan penambahan 1 tetes $\mathrm{HCl} 2 \mathrm{~N}$ menunjukkan adanya saponin.

4) Prosedur UjiTriterpenoid 
Sebanyak $1 \mathrm{~g}$ simplisia dimaserasi dengan $20 \mathrm{ml}$ petroleum eter selama 2 jam kemudian disaring. Filtrat diuapkan dalam cawan penguap dan pada sisanya ditambahkan 10 tetes asam asetat anhidrat dan 1 tetes asam sulfat pekat (pereaksi Liebermann-Burchard). Apabila terbentuk warna ungu atau merah yang berubah menjadi biru hijau menunjukkan adanya steroid/triterpenoid.

5) Prosedur Uji Kafein

Disiapkan larutan kopi, dengan cara ditimbang terlebih dahulu serbuk kopi sebanyak 2 g kemudian dilarutkan dalam $50 \mathrm{ml}$ air panas dan diaduk. Dipipet larutan kopi sebanyak 2 tetes dimasukkan ke dalam tabung reaksi ditambahkan etanol 2 tetes, reagen parry 1 tetes dan $\mathrm{NH}_{4} \mathrm{OH} 1$ tetes. Diamati perubahan warna yang terjadi, jika larutan berwarna biru tua/hijau dinyatakan terdapat kafein.

\section{E. Uji Organoleptik}

Bubuk kopi biji pepaya sebanyak $2 \mathrm{~g}$ diseduh dengan $50 \mathrm{ml}$ air panas dan ditambahkan $1 \mathrm{~g}$ gula. Setiap sampel seduhan kopi biji pepaya ditempatkan digelas/botol yang berbeda, kemudian diberikan kepada panelis. Panelis mengisi form penilaian yang sudah diberikan. Kriteria penilaian pada form meliputi rasa, warna dan aroma. Skala yang digunakan yaitu $9=$ sangat suka sekali, $8=$ sangat suka, $7=$ suka, $6=$ agak suka, $5=$ biasa, $4=$ agak tidak suka, $3=$ tidak suka, 2 $=$ sangat tidak suka, $1=$ sangat tidak suka sekali. Data dikumpulkan.

\section{HASIL DAN PEMBAHASAN}

Desain pembuatan kopi biji pepaya ini dilakukan dengan dua tahapan yaitu tahap optimasi cara pengeringan dan tahap optimasi waktu penyangraian. Kedua tahap ini dilakukan untuk mendapatkan hasil produk terbaik, dari segi rasa, warna, aroma maupun dari kandungan biji pepaya tersebut.

\section{A. Optimasi Cara Pengeringan}

\section{Uji Fitokimia}

Berdasarkan uji fitokimia yang dilakukan terhadap sampel kopi biji pepaya diperoleh hasil yang disajikan pada Tabel 1.

Tabel 1. Hasil uji fitokimia optimasi cara pengeringan

\begin{tabular}{|c|c|c|c|c|}
\hline \multirow{2}{*}{ Sampel } & \multicolumn{4}{|c|}{ Hasil Kandungan Senyawa Kimia } \\
\cline { 2 - 5 } & Alkaloid & Flavonoid & Saponin & Triterpenoid \\
\hline A & + & + & + & - \\
\hline B & + & + & + & - \\
\hline C & + & - & - & - \\
\hline
\end{tabular}

Keterangan :

A $\quad:$ Perlakuan pengeringan dengan sinar matahari

B $\quad$ : Perlakuan pengeringan dengan suhu ruang 
C : Perlakuan pengeringan dengan oven

$+\quad$ : Mengandung Alkaloid/Flavonoid/Saponin/Triterpenoid

- $\quad$ : Tidak mengandung Alkaloid/Flavonoid/Saponin/Triterpenoid

\section{Uji Organoleptik}

Berdasarkan uji organoleptik yang telah dilakukan terhadap sampel kopi biji pepaya dengan pengujian kepada 20 orang panelis tidak terlatih diperoleh nilai rata-rata yang disajikan pada Gambar 1 .

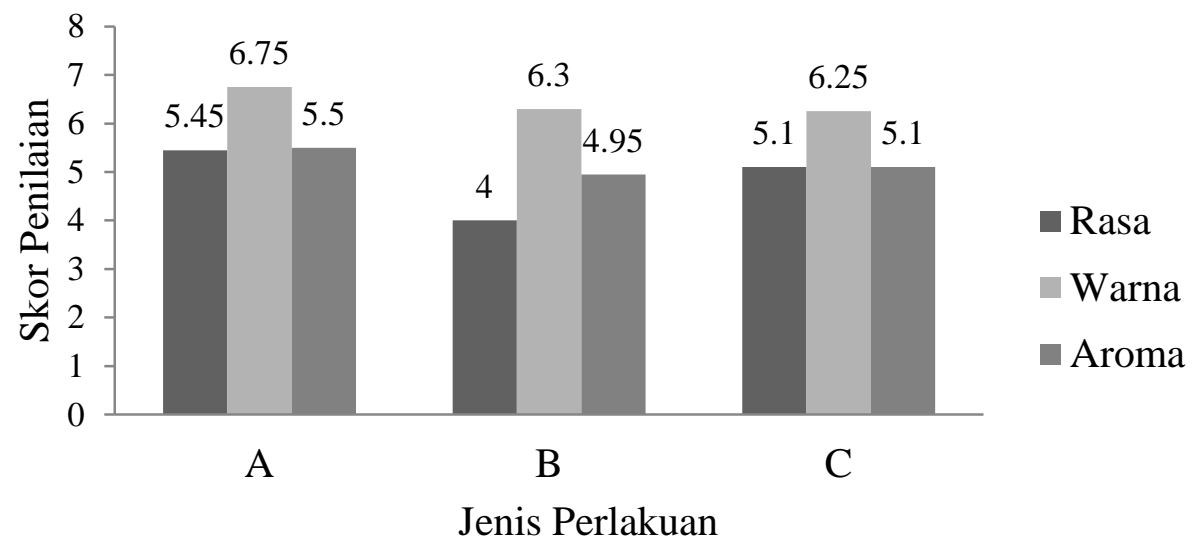

Gambar 1. Hasil Uji Organoleptik Optimasi Cara Pengeringan.

\section{B. Optimasi Waktu Penyangraian Uji Kadar Air dan Uji Fitokimia}

Berdasarkan uji kadar air dan uji fitokimia yang dilakukan terhadap sampel kopi biji pepaya diperoleh hasil yang disajikan pada Tabel 2.

Tabel 2. Hasil uji kadar air dan uji fitokimia optimasi waktu penyangraian

\begin{tabular}{|c|c|c|c|c|c|c|}
\hline \multirow{2}{*}{ Sampel } & \multirow{2}{*}{$\begin{array}{c}\text { Kadar Air } \\
(\boldsymbol{\%})\end{array}$} & \multicolumn{5}{|c|}{ Hasil Kandungan Senyawa Kimia } \\
\cline { 3 - 7 } & & Alkaloid & Flavonoid & Saponin & $\begin{array}{c}\text { Triterpenoi } \\
\mathbf{d}\end{array}$ & Kafein \\
\hline A1 & 9,00 & + & + & + & - & - \\
\hline A2 & 7,00 & + & + & - & - & - \\
\hline A3 & 4,67 & - & - & - & - & - \\
\hline
\end{tabular}

Keterangan :

A1 : Perlakuan penyangraian selama 5 menit

A2 : Perlakuan penyangraian selama 10 menit

A3 : Perlakuan penyangraian selama 15 menit

$+\quad$ : Mengandung Alkaloid/Flavonoid/Saponin/Triterpenoid/Kafein

- $\quad$ : Tidak mengandung Alkaloid/Flavonoid/Saponin/Triterpenoid/Kafein

\section{Uji Organoleptik}

Berdasarkan uji organoleptik yang telah dilakukan terhadap sampel kopi biji pepaya dengan pengujian kepada 20 orang panelis tidak terlatih diperoleh nilai rata-rata yang disajikan pada Gambar 2. 


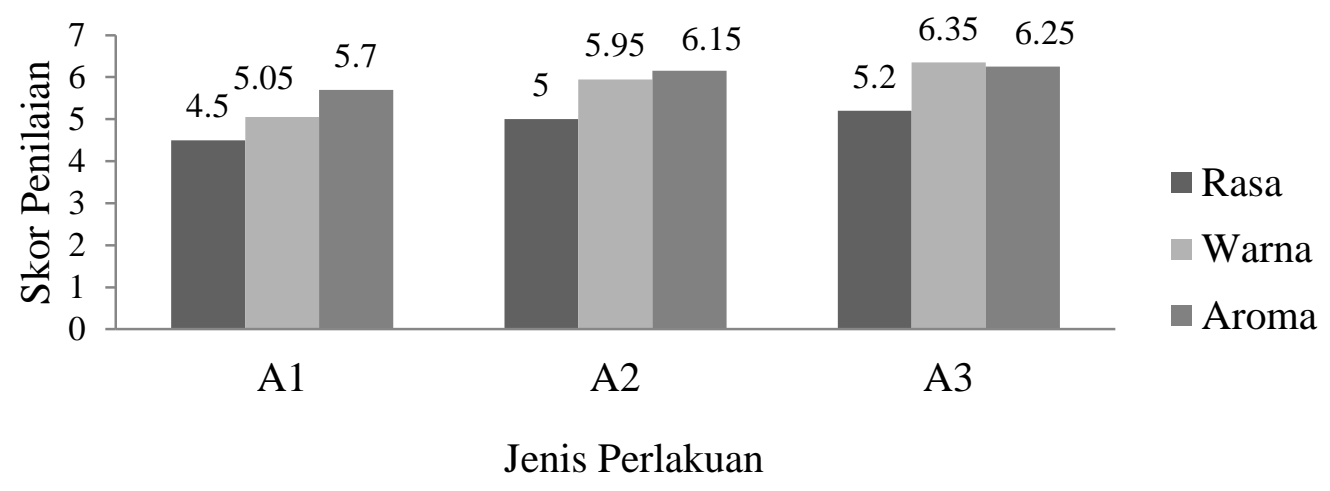

Gambar 2. Hasil Uji Organoleptik Optimasi Waktu Penyangraian.

Berdasarkan hasil dari uji kadar air, uji fitokimia dan uji organoleptik diperoleh hasil produk terbaik adalah kopi biji pepaya dengan waktu penyangraian 10 menit dengan kadar air 7\%, dengan kandungan senyawa metabolit sekunder alkaloid dan flavonoid serta hasil skor penilaian rata-rata panelis untuk rasa 5 (biasa), warna 5,95 (biasa) dan aroma 6,15 (agak suka). Walaupun diketahui kopi biji pepaya dengan waktu penyangraian 15 menit memiliki kadar air yang lebih rendah yaitu 4,67\% dan hasil uji organoleptik dengan penilaian skor rata-rata sedikit lebih tinggi dibandingkan kopi biji pepaya dengan waktu penyangraian 10 menit, tetapi kadar air kopi biji pepaya dengan waktu penyangraian 10 menit masih memenuhi SNI, dan diketahui kopi biji pepaya dengan waktu penyangraian 15 menit pada uji fitokimia kandungan metabolit sekunder yang diuji yaitu alkaloid, flavonoid, saponin dan triterpenoid dalam sampel tersebut sudah tidak ada lagi sehingga dipilih produk terbaik adalah kopi biji pepaya dengan waktu penyangraian 10 menit. Hal ini sesuai dengan tujuan dari optimasi yang dilakukan yaitu untuk mencapai hasil yang ideal.

\section{KESIMPULAN}

Berdasarkan penelitian yang telah dilakukan dapat diambil kesimpulan bahwa hasil produk terbaik yang diperoleh dari optimasi cara pengeringan adalah kopi biji pepaya dengan pengeringan sinar matahari sedangkan hasil produk terbaik dari optimasi waktu penyangraian adalah kopi biji pepaya dengan waktu penyangraian selama 10 menit. Hasil uji fitokimia kopi biji pepaya mengandung senyawa metabolit sekunder yaitu alkaloid dan flavonoid. Berdasarkan uji organoleptik yang dilakukan dipilih produk terbaik yaitu kopi biji pepaya dengan pengeringan sinar matahari dan waktu penyangraian 10 menit.

\section{DAFTAR PUSTAKA}

Haryanto, B. 1992. Potensi dan Pemanfaatan Sagu. Kanisius : Yogyakarta.

Harborne, J, B. 1987. Penuntun Cara Modern Menganalisis Tumbuhan. Penerbit : ITB, Bandung. Hal. 239.

Markham, K. R. 1988. Cara Mengidentifikasi Flavonoid. Bandung : Penerbit ITB. Hal. 21, 27, 39.

Wagiyono. 2003. Menguji Kesukaan Secara Organoleptik. Direktur Pendidikan Menengah Kejuruan. Jakarta.

Warisno. 2003. Budidaya Pepaya. Kanisius : Yogyakarta. 